\title{
A REVIEW AND EXTENSION OF OUR KNOWLEDGE OF CALYPTOSPORA GOEPPERTIANA KUEHN
}

\author{
J. H. FAULL
}

OUR KNOWLEDGE of the haploid phase of Calyptospora Goeppertiana on Abies dates from 1805 and of the diploid phase on Vaccinium from 1869. That the latter was not recognized earlier is readily understood because there are no uredia, and because the teliospores are intraepidermal with no suggestive external indications of their presence. In 1880, Robert Hartig (13) announced that he had proved the connection of the two phases by means of culture experiments. His findings have been confirmed repeatedly.

Calyptospora Goeppertiana is of special interest not only for its lack of uredia but also for its reduced spermogonia. Indeed, the latter were long supposed to be absent. They do occur, however, and often in considerable numbers. But they are aborted to a greater or less extent and, so far as Hunter (15) could determine from a thorough study of the rust on Abies balsamea, they do not form spermatia nor do they rupture. On the other hand, Weir (21) reported normal spermogonia and spermatia for $C$. Goeppertiana on A. lasiocarpa. If that occurrence is representative for the rust in western North America, then it differs from what is known of it in Europe and eastern North America. Before re-defining the species, however, Weir's observations should be checked against those made on unquestionably authentic $C$. Goeppertiana, preferably from cultures on A. lasiocarpa in which telial material from Europe or eastern North America would be used as inoculum.

Another feature of interest concerning $C$. Goeppertiana is its phylogeny. Plainly, as has been maintained by Faull (9) and others, the characteristics of its spermogonia, aecia and teliospores suggest a close relation to Pucciniastrum. From a comparative investigation of the ontogeny of the teliospores in the various genera of the Pucciniastreae, Pady (19), while recognizing the resemblance of Calyptospora to Pucciniastrum, inclines to the view that they may be analogous genera in parallel evolutions. He concludes — "These results agree in a very general way with the phylogenetic tree that Faull has constructed for the Pucciniastreae, except for the possibility that the two lines of development indicated above might represent two phylogenetic series. In that case, 
the phylogenetic tree would possess two main branches, the one leading through the intra-epidermal forms, Milesia, Hyalopsora, Thecopsora and Calyptospora, and the other passing through the subepidermal genera Pucciniastrum and Melampsoridium, to such forms as Melampsora. Many more data would be necessary, however, before this series could be postulated as a phylogenetic one."

Economically, C. Goeppertiana is probably not of great importance. Yet I have found it on seedlings of Abies balsamea in the forest in such abundance as to indicate some effect on the natural reproduction of that species. Weir (21) also reports that in the western United States it is injurious to various species of Vaccinium. But so far no exact investigation seems to have been made on that aspect of the rust.

This paper deals with four topics relative to C. Goeppertiana, namely, (1) nomenclature and taxonomy, (2) life history studies, (3) hosts, (4) specimens examined.

\section{NOMENCLATURE AND TAXONOMY}

Calyptospora Goeppertiana Kühn in Hedw. 8: 81 (1869). (III).

Aecidium columnare Albertini \& Schwein. Consp. Fung. Lusat. 121 (1805). (I).

Peridermium columnare Kze. \& Schm. Deutschl. Schwämme no. 10 (1815). (I).

Caeoma columneum Link in W. Spec. P1. 6, 2: 66 (1825). (I).

Uredo columnaris Spreng. Syst. Veg. 4, 1: 570 (1827). (I).

Melampsora Goeppertiana Wint. in Rabenhorst, Krypt.-Fl. ed. 2. 1: 245 (1884).

Melampsora columnaris Wettst. in Verhandl. Zool.-Bot. Ges. Wien, 35: 551 (1885).

Calyptospora columnaris Kühn in Rabenh.-Wint. Fung. Eur. no. 3521 (1886).

Pucciniastrum Goeppertianum Kleb. Wirtswechs. Rostpilze, 391 (1904).

Thecopsora Goeppertiana Hiratsuka in Jour. Soc. Agric. Forestr. Sapporo, 19: 167 (1927).

After it was experimentally demonstrated that Aecidium columnare A. \& S. on Abies and Calyptospora Goeppertiana Kühn on various species of Vaccinium are the haploid and the diploid phases, respectively, of the same species, the nomenclatural history of this rust has mainly revolved around the proper choice of the specific and the generic names. The authoritative specific name was settled eventually by Article 49 bis of the rules adopted by the International Botanical Congress of 1910 . The choice of generic name is still subject to differences of opinion.

Just what generic name should be adopted depends on breadth of interpretation and on the measure of regard for long established usage. 
Three names are involved, namely, Calyptospora, Pucciniastrum, Thecopsora. Morphologically, the rusts variously referred to these genera are similar with respect to their aecia and teliospores. This fact has been deemed sufficient by some systematists to warrant the inclusion of all of them under Pucciniastrum, a name which has priority over the other two. Another view is held to the effect that a separation of these rusts should be made according to whether their teliospores are subepidermal or intraepidermal. Under that disposition they are distributed between the respective genera Pucciniastrum and Thecopsora. But many uredinologists prefer to retain $C$. Goeppertiana under the generic name Calyptospora, partly because of long established usage, as so frankly admitted by Sydow (20), and partly because C. Goeppertiana is characterized by such important distinctive features as more or less aborted, apparently non-functional spermogonia, lack of uredia, cauline teliospores and indeterminate telia which occupy the entire epidermides of "broomed" stems.

Up to this point the synonymy involved centers on what is universally regarded as the same fungus. Quite recently, however, Arthur (2) has added two synonyms concerning which there may be some question of fungus identity, namely, Peridermium ornamentale Arthur (in Bull. Torr. Bot. Club, 28: 665. 1901) and P. Holwayi Sydow (in Ann. Mycol. 1: 19. 1903). The former was collected Sept. 4, 1900 on Mt. Paddow, Washington at an elevation of about 6000 feet on first year needles of Abies lasiocarpa. The latter was described from material collected Aug. 11, 1901 at Glacier, B. C., on second year needles of A. lasiocarpa. After careful study of the types, I am convinced that neither is Calyptospora Goeppertiana, and that both are probably specifically distinct from each other. Table 1 presents the data on which these conclusions are based.

In this connection it should be noted that the usual practice in herbaria nowadays is to label specimens of these rusts from the western United States and western Canada with the name Peridermium ornamentale, regardless of whether the peridermia are on first or second year needles. No recognition is being given to $P$. Holwayi other than to regard it as a synonym. According to the present state of our knowledge, this procedure is without warrant. In short, I tentatively agree with the opinion expressed by Boyce (6) that $P$. ornamentale, as now generally interpreted, "is undoubtedly a composite species, because Peridermia with aecia on the current season's needles and others with aecia on the one-year-old needles are so named."

Just what the diploid phases of Peridermium ornamentale and $P$. 
TABLE 1

COMPARISON OF CALYPTOSPORA GOEPPERTIANA, PERIDERMIUM ORNAMENTALE AND P. HOLWAYI

\begin{tabular}{|c|c|c|c|}
\hline & $\begin{array}{l}\text { Calyptospora } \\
\text { Goeppertiana } \\
\text { on } \\
\text { Abies balsamea } \\
\text { (Culture) }\end{array}$ & 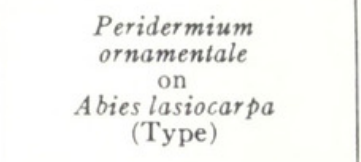 & $\begin{array}{c}\text { Peridermium } \\
\text { Holwayi } \\
\text { on } \\
\text { Abies lasiocarpa } \\
\text { (Type) }\end{array}$ \\
\hline $\begin{array}{l}\text { Position of } \\
\text { spermogonia }\end{array}$ & Hypophyllous & $\begin{array}{l}\text { Amphigenous, but } \\
\text { mostly hypophyl- } \\
\text { lous }\end{array}$ & $\begin{array}{l}\text { Amphigenous; abun- } \\
\text { dant on both sur- } \\
\text { faces }\end{array}$ \\
\hline $\begin{array}{l}\text { Condition of } \\
\text { spermogonia }\end{array}$ & $\begin{array}{l}\text { More or less aborted } \\
\text { and apparently not } \\
\text { functional }\end{array}$ & $\begin{array}{l}\text { Not aborted and ap- } \\
\text { parently functional }\end{array}$ & $\begin{array}{l}\text { Not aborted and ap- } \\
\text { parently functional }\end{array}$ \\
\hline $\begin{array}{l}\text { Limits of } \\
\text { size of } \\
\text { spermogonia }\end{array}$ & $13-30 \times 42-137 \mu$ & $32-54 \times 81-175 \mu$ & $27-54 \times 68-138 \mu$ \\
\hline $\begin{array}{l}\text { Average size } \\
\text { of sper- } \\
\text { mogonia }\end{array}$ & $21 \times 73 \mu$ & $40 \times 126 \mu$ & $35 \times 98 \mu$ \\
\hline $\begin{array}{l}\text { Occurrence of } \\
\text { peridermia }\end{array}$ & $\begin{array}{l}\text { 1st year needles } \\
\text { Hypophyllous }\end{array}$ & $\begin{array}{l}\text { 1st year needles } \\
\text { Hypophyllous }\end{array}$ & $\begin{array}{l}\text { 2nd year needles } \\
\text { Hypophyllous }\end{array}$ \\
\hline $\begin{array}{l}\text { Seasonal oc- } \\
\text { currence of } \\
\text { peridermia }\end{array}$ & $\begin{array}{l}\text { Early summer of } \\
\text { first year }\end{array}$ & $\begin{array}{l}\text { Late summer or early } \\
\text { autumn of first year }\end{array}$ & $\begin{array}{l}\text { Summer or late } \\
\text { spring of second } \\
\text { year }\end{array}$ \\
\hline $\begin{array}{l}\text { Shape and } \\
\text { size of } \\
\text { peridermia }\end{array}$ & Slender, terete & $\begin{array}{l}\text { Robust, cylindrical } \\
\text { to compressed } \\
\text { cylindrical }\end{array}$ & $\begin{array}{l}\text { Robust, compressed } \\
\text { cylindrical }\end{array}$ \\
\hline $\begin{array}{l}\text { Average } \\
\text { size of } \\
\text { aeciospores }\end{array}$ & $16 \times 20 \mu$ & $14 \times 20 \mu$ & $18 \times 23 \mu$ \\
\hline
\end{tabular}

Notes:

(1) Spermogonia of all three are flattened convex, subcuticular.

(2) The occurrence of the spermogonia as hypophyllous or amphigenous might possibly vary according to the host species, just as was found by Faull (10) to be true of Milesia fructuosa.

(3) The average size of the spermogonia might possibly vary within fairly wide limits. This could be determined only by the examination of many collections of authentically named specimens.

(4) The robustness and the shape of the peridermia might possibly vary according to the host species or according to nutritional and environmental factors.

(5) Whether or not a rust might form its peridermia in the latter part of the first year or the early part of the second year, depending on seasonal or other factors, is unknown. But so far this has never been demonstrated for any species. If it be true of $P$. ornamentale or $P$. Holwayi, then one important reason would be removed for regarding them as distinct species. 
Holwayi may be, remains for cultural determination. Their characteristics, however, indicate a Pucciniastrum relationship. Such, too, is Boyce's view (5), although his surmise, based on field associations of the rusts, that Pucciniastrum Myrtilli on Vaccinium is the diploid phase of Peridermium ornamentale is quite improbable. Pucciniastrum Myrtilli is known to have Tsuga as its alternate host, and all attempts so far to culture it on Abies have failed. If Peridermium ornamentale does infect Vaccinium, then the resulting diploid phase might resemble that of Pucciniastrum Myrtilli; but with at least equal likelihood it might resemble that of Calyptospora Goeppertiana. The same applies to Peridermium Holwayi. That there may be a second species of Calyptospora, as yet unnamed, in western North America has already been suggested by Weir (21) in his comparative study of what he took to be Calyptospora Goeppertiana. His conclusion was influenced solely by differences in the shape and the robustness of the peridermia characteristic of $C$. Goeppertiana and P. ornamentale. He expressed himself as follows - "It is here proposed to reverse an earlier view on the identity of the aecial form on Abies with large cylindrical or flattened peridia and suggest the probability of there being another species of Calyptospora with telia on Vaccinium. This suggestion is based purely on field observations. All collections of the large aecial form so far made by the writer have been in close association with the typically appearing telial stage on Vaccinium. Wherever the large aecial form has been collected the form with small cylindrical peridia has been absent, with the reverse as true." He adds, - "Another view," apparently not his own, "would be that the size of the aecia is influenced by the vigor of the host and that the two forms are identical." Incidentally it should be remarked that if there be a second species of Calyptospora on Vaccinium in western North America, then the collections labelled C. Goeppertiana from that part of the world are subject to revision.

Here, then, is a simple, well defined problem in western North America that can be solved by making suitable cultures - the problem of adequately defining the rusts included under the names Calyptospora Goeppertiana, Peridermium ornamentale and Peridermium Holwayi.

\section{LIFE HISTORY STUDIES}

Several successful life history studies have been made of Calyptospora Goeppertiana. Robert Hartig $(13,14)$ cultured it from Vaccinium Vitis-idaea on Abies alba, and then in the reverse direction. He made no mention of spermogonia. Kühn $(16,17,18)$ then cultured it from V. Vitis-idaea on Abies alba, A. balsamea, A. cephalonica, A. cilicica, 
A. concolor, A. Fraseri, A. magnifica, A. nobilis, A. Nordmanniana, A. Pinsapo, A. sibirica and A. Veitchii. He also made no mention of spermogonia. Bubák $(7,8)$ cultured it from V. Vitis-idaea on A. alba. No spermogonia were recognized. Arthur (1) cultured it from $V$. pennsylvanicum on A. Fraseri. He remarked, "pycnia rarely if ever found." Fraser $(11,12)$ cultured it from $V$. pennsylvanicum on $A$. balsamea. No spermogonia were recognized. He also inoculated Tsuga canadensis with telial material, but the results were negative. Weir $(21)^{*}$ cultured a rust, which he took to be $C$. Goeppertiana, from A. lasiocarpa on $V$. membranaceum. In other experiments he cultured the rust from brooms of $V$. membranaceum on A. lasiocarpa, and also carried it forward from Vaccinium to Vaccinium by making infected tissue plantings. Finally, I have made many cultures on A. balsamea, using as inoculum telial material from $V$. pennsylvanicum and $V$. canadense. Summaries of my experiments are recorded in Tables 2 and 3 of this paper.

\section{TABLE 2}

\section{CULTURES OF CALYPTOSPORA GOEPPERTIANA FROM VACCINIUM PENNSYLVANICUM TO ABIES BALSAMEA}

1. Forty-five inoculation experiments were made; all gave positive results.

2. The dates of inoculation ranged from June 8 to June 20 .

3. Yellowing of the needles appeared 12 to 17 days after inoculation. The average was 14 days.

4. Spermogonia were first observed 13 to 19 days after inoculation. The average was 16 days.

5. The peridermia were first observed 17 to 24 days after inoculation. The average was 21 days.

6. The peridermia began to rupture one to five days following their first appearance.

7. The production of peridermia was practically completed within 32 days after inoculation. The average was about 29 days.

*Through the courtesy of the United States Bureau of Plant Industry I have had the opportunity of examining an unused part of Weir's aecial inoculum from Abies lasiocarpa, and also meager infections on $A$. lasiocarpa that resulted from his inoculations with telial material of Vaccinium membranaceum origin. I would be hesitant, however, to unreservedly pronounce either as Calyptospora Goeppertiana. Spermogonia do occur on both of them, though with comparative scantiness. No distinctly aborted spermogonia were found; but I could not determine whether or not spermatia were produced. Certainly the peridermia are more robust than those characteristic of $C$. Goeppertiana on Abies balsamea and not less so than some of Peridermium ornamentale. Moreover, the first material referred to above was collected after the middle of September, which suggests a long developmental period as compared with the few weeks required for the development of $C$. Goeppertiana on A. balsamea. 
8. The number of infected needles with peridermia varied from 6 to 203 . The average was 70 .

9. The number of peridermia per needle varied from 22 to 41 . The average was 27.

10. J. H. Faull Herbarium nos. 7269-7279, 7403 and 8116-8132.

TABLE 3

\section{CULTURES OF CALYPTOSPORA GOEPPERTIANA FROM VACCINIUM CANADENSE TO ABIES BALSAMEA}

1. Three inoculation experiments were made; all gave positive results.

2. The date of inoculation was June 22 .

3. Yellowing of the needles appeared 11 to 13 days after inoculation. The average was 12 days.

4. The spermogonia were first observed 13 to 15 days after inoculation. The average was 14 days.

5. The peridermia were first observed 21 days after inoculation.

6. The peridermia began to rupture two days following their first appearance.

7. The production of peridermia was practically completed within 25 days after inoculation.

8. The number of infected needles with peridermia varied from 75 to 108 . The average was 90.

9. The number of peridermia per needle varied from 27 to 41 . The average was 33 .

10. J. H. Faull Herbarium nos. 8133-8135.

\section{HOSTS}

The haploid phase of Calyptospora Goeppertiana has been shown by cultures to have as hosts the following species of Abies - 1. Abies alba Mill. 2. A. balsamea (L.) Mill. 3. A. cephalonica Loud. 4. A. cilicica Carr. 5. A. concolor Lindl. \& Gord. 6. A. Fraseri (Pursh) Lindl. 7. A. lasiocarpa Nutt. 8. A. magnifica A. Murr. 9. A. nobilis Lindl. 10. A. Nordmanniana Spach. 11. A. Pinsapo Boiss. 12. A. sibirica Ledeb. 13. A. Veitchii Lindl. Other species of Abies have been recorded as hosts but they have not been confirmed by cultures. It would seem probable, however, from this list that most, if not all, species of Abies are susceptible to C. Goeppertiana.

The diploid phase of $C$. Goeppertiana occurs on the following species of Vaccinium - 1. Vaccinium canadense Kalm. 2. V. corymbosum L. 3. V. Myrtillus L. 4. V. pennsylvanicum Lam. 5. V. vacillans Kalm. 6. V. Vitis-idaea L. 7. V. Vitis-idaea var. minus Lodd. 
Many species from western North America are also recorded as hosts of C. Goeppertiana. But, for reasons already expressed, the determinations may be subject to revision. Nevertheless it is probable that they, too, may serve as hosts for this rust. The list is as follows Vaccinium caespitosum Michx., V. Chandleri Jepson, V. erythrococcum Rydb., V. membranaceum Dougl., V. microphyllum Rydb., V. oreophilum Rydb., V. ovalifolium Sm., V. ovatum Pursh, V. parvifolium Sm., V. scoparium Leib.

\section{SPECIMENS EXAMINED}

$\mathrm{O}$ and I. On Abies alba.

Germany: München, July 1910, J. H. Faull.

$\mathrm{O}$ and I. On Abies balsamea.

Nova Scotia : Card Lake, July 21, 1929, J. H. Faull. - Mahone, July 22, 1929, J. H. Faull. - Liscomb Park, July 30, 1929, J. H. Faull.

Ontario: Timagami, July 4, 16, 25, 1919, J. H. Faull. - Timagami, July 10-16, 1924; Cultures from Vaccinium pennsylvanicum by J. H. Faull and W. G. Watson. - Timagami, July 11, 1925; Cultures from $V$. pennsylvanicum by E. H. Moss. - Timagami, July 16-19, 1926; Cultures from $V$. pennsylvanicum by J. H. Faull and G. D. Darker. - Timagami, July 17-18, 1926; Cultures from $V$. canadense by J. H. Faull and G. D. Darker. - Timagami, July 12, 1927, G. D. Darker 2041.

III. On Vaccinium canadense.

Maine: Eustis, Oct. 23, 1931, J. H. Faull.

Ontario: Timagami, Aug. 19, 1921, J. H. Faull. - Timagami, May 12, 1924, J. H. Faull.

Quebec: Mt. Albert, Gaspé Co., Aug. 21, 1933, J. H. Faull.

III. On Vaccinium pennsylvanicum.

Maine: Eustis, Oct. 23, 1931, J. H. Faull. - Solon, Aug. 27, 1935, J. H. Faull.

New Hampshire: Mt. Jefferson, Aug. 31, 1932, J. H. Faull.

Nova Scotia: Card Lake, July 21, 1929, J. H. Faull. — Liscomb Park, July 30, 1929, J. H. Faull.

Ontario: Timagami, July 5, 16, 29, 1919, J. H. Faull. - Timagami, June 18, 1923, J. H. Faull. - Timagami, July 8, 1924, J. H. Faull. Timagami, May 31, 1925, J. H. Faull.

III. On Vaccinium Vitis-idaea.

Alberta : Mercoal, Aug. 8, 1925, W. R. Watson.

JAPAn : Mt. Oakan, Prov. Kushiro, Aug. 21, 1926, N. Hiratsuka 546.

III. On Vaccinium Vitis-idaea var. minus.

New Hampshire: Mt. Jefferson, Aug. 31, 1932, J. H. Faull.

\section{SUMMARY}

1. A review of the literature indicates that thirteen species of Abies have been proved by experiments to be susceptible to Calyptospora Goeppertiana Kühn. None are known to be immune. 
Likewise, many species of Vaccinium have been recorded as hosts of C. Goeppertiana. A few of them have been used in making life history studies of the rust, namely, V. Vitis-idaea, V. pennsylvanicum and possibly $V$. membranaceum by previous investigators, and $V$. pennsylvanicum and $V$. canadense by the writer.

2. Life history studies made by the writer are summarized in Tables 2 and 3 of this paper. In these, C. Goeppertiana was successfully passed from Vaccinium pennsylvanicum and V. canadense to Abies balsamea.

3. Peridermium ornamentale Arthur and P. Holwayi Sydow, more recently held to be synonymous with $C$. Goeppertiana Kühn, are compared (Table 1) with one another and with the haploid phase of $C$. Goeppertiana. The disagreements noted lead to the conclusion that they are probably distinct forms and that neither is C. Goeppertiana. The diploid phases of $P$. ornamentale and $P$. Holwayi, interpreting these forms from their type specimens, have not yet been demonstrated.

4. So far, one species only of Calyptospora has been described. If, however, $P$. ornamentale and $P$. Holwayi should prove to be as yet unnamed species of Calyptospora, then the identification of collections from western North America, now passing under the name $C$. Goeppertiana, is subject to revision. The answer awaits culture experimentation.

5. The record of specimens studied in connection with the preparation of this paper extends our knowledge of the geographical distribution of $C$. Goeppertiana and gives recognition to V. Vitis-idaea var. minus Lodd. as a host of that rust.

\section{LITERATURE CITED}

1. Arthur, J. C. Cultures of Uredineae in 1909. (Mycologia 2:231. 1910.)

2. 19. Manual of the rusts in United States and Canada, 19-20. 1934.

3. - and F. D. Kern. North American species of Peridermium. (Bull. Torr. Bot. Club 33: 431-433. 1906.)

4. Bell, H. P. Fern rusts of Abies. (Bot. Gaz. 77: 23. 1924.)

5. Boyce, J. S. A possible alternate state of Pucciniastrum Myrtilli (Schum.) Arth. (Phytopath. 18:623-625. 1928.)

6. A conspectus of needle rusts on balsam firs in North America. (Phytopath. 18: 705-708. 1928.)

7. BüÁK, Fr. Vorläufige Mitteilung über Infektionsversuche mit Uredineen in Jahre 1904. (Ann. Mycol. 2: 361. 1904.)

8. - Infektionsversuche mit einigen Uredineen. Bericht III. (Centralbl. Bakt. 2: 154. 1906.)

9. Faull, J. H. The morphology, biology and phylogeny of the Pucciniastreae. [Proc. Internat. Congr. Plant Sci. Ithaca (1926) 2: 17351745. 1929.]

10. The biology of Milesian rusts. (Jour. Arnold Arb. 15: 50-85. 1934.) 
11. Fraser, W. P. Cultures of heteroecious rusts. (Mycologia 4: 177 .

12. $\frac{1912 .)}{1914 .)}$ Notes on Uredinopsis and other rusts. (Mycologia 6:27.

13. Hartig, R. Calyptospora Goeppertiana Kühn und Aecidium columnare A. \& S. (Allgem. Forst- und Jagdzeit. 289. 1880.)

14. Uber Aecidium columnare A. \& S. und Calyptospora Goeppertiana Kühn. (Flora 64: 45. 1881.)

15. Hunter, L. M. Comparative study of spermogonia of rusts of Abies, (Bot. Gaz. 83: 1-23. 1927.)

16. KüHn, J. Calyptospora nov. gen. Uredinearum. (Hedwigia 8:81. 1869.)

17. Notiz zu no. 3027 der Fungi Europaei, das Aecidium columnare betreffend. (Hedwigia 24: 108. 1885.)

18. Calyptospora columnaris Kühn no. 3521 in Rabenhorst's Fungi Europaei. (Hedwigia 26: 28. 1887.)

19. Pady, S. M. Teliospore development in the Pucciniastreae. (Canadian Jour. Res. 9: 458-485. 1933.)

20. Sydow, P. \& H. Monographia Uredinearum 3: 470-472. 1915.

21. Weir, J. R. Observations on Calyptospora columnaris and Peridermium ornamentale. (Mycologia 18: 274-277. 1926.)

Laboratory of Plant Pathology,

Arnold Arboretum, Harvard University. 


\section{$2 \mathrm{BHL}$ Biodiversity Heritage Library}

Faull, J. H. 1939. "A Review and Extension of Our Knowledge of Calyptospora goeppertiana Kuehn." Journal of the Arnold Arboretum 20(1), 104-113. https://doi.org/10.5962/p.185400.

View This Item Online: $\underline{\text { https://www.biodiversitylibrary.org/item/33596 }}$

DOI: https://doi.org/10.5962/p.185400

Permalink: https://www.biodiversitylibrary.org/partpdf/185400

\section{Holding Institution}

Missouri Botanical Garden, Peter H. Raven Library

\section{Sponsored by}

Missouri Botanical Garden

\section{Copyright \& Reuse}

Copyright Status: In copyright. Digitized with the permission of the rights holder.

Rights Holder: Arnold Arboretum of Harvard University

License: http://creativecommons.org/licenses/by-nc-sa/3.0/

Rights: https://biodiversitylibrary.org/permissions

This document was created from content at the Biodiversity Heritage Library, the world's largest open access digital library for biodiversity literature and archives. Visit BHL at https://www.biodiversitylibrary.org. 